\title{
Review
}

\section{The future of whiteness}

\author{
Linda Martín Alcoff \\ Polity Press, Cambridge, UK and Malden, MA, 2015, viii+223pp., ISBN-13: \\ 978-0745685458 (paper); ISBN-13: 978-0745685441 (hardbound)
}

Contemporary Political Theory (2016) 15, e44-e47. doi:10.1057/cpt.2016.9; advance online publication 22 March 2016

Within the next few decades white people will lose their majority status in the United States and perhaps also in parts of Europe. This is the context in which Linda Martín Alcoff sets out to ask whether there could be 'a place in the rainbow' for whites: could whites become just an 'ordinary' group among others in the rainbow, or is whiteness - as critical race theorists and whiteness studies scholars most often argue - so intrinsically tied to racism and white supremacy as to make this impossible? Alcoff is well aware of the racist baggage, the supremacist claims and privileges that continue to accompany whiteness. Even so, she argues that a place for whites qua white in the rainbow is possible and desirable. The intended audience for this book is mainly antiracist progressives, among whom Alcoff has long established her own credentials as an activist and critical thinker. She insists that it is now imperative for them to consider how whiteness could become lived or 'inhabited' as a positive identity that is delinked from racism.

The history of whiteness, as Alcoff nicely exemplifies, is complex and far from homogenous, and its future meanings, too, are in principle multiple and open. Accordingly, she argues 'against the idea that white identity cannot adapt in positive ways to a loss of centrality [for] it is not at all clear that, without white supremacy, there can be no whiteness' (p. 19). To the contrary, she insists, the 'essentializing of whiteness as necessarily, fundamentally and centrally about white supremacy is simply ahistorical, and based in a wrong understanding of how meanings operate as well as of how social identities are formed' (pp. 19-20). Essentializing whiteness is not only conceptually misguided, it is also politically counterproductive. What she calls 'antiracist white exceptionalism', wherein whiteness is conceived as nothing but a project of race supremacy, has serious costs for progressive politics. For exceptionalism not only expunges numerous instances of transracial collective action from the historical record but also obscures potential sites for such action today.

In addition to rejecting essentialist conceptions of race, Alcoff also criticizes those alternative views she calls 'eliminativism'. By eliminativism she refers to left-wing

(C) 2016 Macmillan Publishers Ltd. 1470-8914 Contemporary Political Theory Vol. 15, 4, e44-e47 www.palgrave.com/journals 
versions of 'post-racialism' that seek to deny the 'reality' of race, that view naming race as itself contributing to racism, or that claim racial categories are now becoming irrelevant (p. 149). For social identities, including but not limited to race, carry 'ontological weight'. Even though they are more fluid than essentialists grant, they remain 'real'. 'A realist view', she argues, 'understands identities to be significant aspects of the social world and of our lived sense of who we are and how we are positioned in the immediate social environs in which we live and work' (p. 45). Thus, they make sense of the world for us, and they involve material, embodied and visible practices. They are imbued with systems of collective meaning, and they locate us within shifting historical and hermeneutic horizons. Alcoff painstakingly, and in my view persuasively, carves out a conceptual middle ground where social identities in general and race identities in particular are neither essentialized nor erased.

In what ways, then, is whiteness 'real'? Although race is not a viable biological category it remains real as a 'social kind', she argues. Its objective economic and other empirical effects can be measured, its dominant collective cultural imaginary persists, and its role in 'the constitution of individual subjects with particular ways of experiencing and perceiving as well as interacting with the social and natural environment' (p. 74) cannot be ignored. Thus, she criticizes recent neo-Marxist work, such as that of Piketty, for ignoring the ways in which race is integral to the history of capitalism (p. 68). She also argues against claims that the category of whiteness has no real content because there are only multiple ethnic identities into which it dissolves. It is true that Jews, Italians or Irish were once excluded from being 'white' but are now included, that other groups are now ambiguously located on its margins, and that 'mixed' identities are becoming increasingly common. Indeed, Alcoff's characterization of her own identity as being 'on the margins' of whiteness - she is, she recounts, the light-skinned child of a Panamanian father and a Southern, poor white mother of Irish origin (pp. 32-36) - itself epitomizes the complexities of whiteness. Yet, for all its internal differentiations whiteness remains - and will remain for the foreseeable future - a powerful, reality-shaping social phenomenon. The question, then, to which Alcoff turns in the later sections of the book is how whiteness may productively be lived in ways that are not intrinsically tied to racism. 'What would it mean for whites to become more positively embodied as white within a multipolar social landscape?' she asks (p. 176).

The later sections the book that address this question are less finely argued than the critiques of essentialism and eliminativism, and they tend to skim, sometimes rather uncritically, across diverse social science materials. However, Alcoff also draws insightfully on examples from film and autobiography as resources. White guilt, compassion or moral outrage are most often presumed to supply the main motives for why some whites become 'allies' in antiracist struggles. Moving beyond (while not discounting) such assumptions, Alcoff makes the important argument that white interests now are key to white transformation. Although challenges to white supremacy can incite reactionary responses such as the Tea Party, she argues there 
are also increasing 'positive' motivations for whites - on their own behalf 'to reassess the meaning of whiteness' (p. 175). These include their inability to make sense of their present economic and cultural predicaments without grasping the historical effects of racism, the impossibility of virtually any effective labor or political action except in cross-racial coalitions, and the discomfort that many whites experience in a world where, in a kind of 'double consciousness', they are increasingly obliged to see themselves through the eyes of their nonwhite neighbors. I suspect Alcoff may underestimate the degree to which a great many whites, even poor ones, still live in worlds insulated from contact with nonwhites and enjoy the benefits of racially segmented labor markets and white cultural preeminence. However, within a longer-term perspective her insistence that we focus on why a white minority may be motivated to 'inhabit' their whiteness positively is of the upmost importance.

Alcoff concludes her book by telling the stories of two white men whose interests lead them - in strikingly divergent ways - to combat white supremacy while also positively inhabiting their whiteness. Bob Zellner was a white field coordinator for the Student Nonviolent Coordinating Committee during the civil rights struggle. What interests Alcoff about him is not only his outstanding dedication to the cause of black rights but his insistence that the Southern racist order was also a violation of white rights, a regime of terror against whites such as himself. She cites Zellner: he was not, he said, acting 'on a missionary impulse', but rather 'joining the movement to establish my own right to fight for what I believed in' (p. 193). Very different is the final story Alcoff relates in the book. This concerns C.P. Ellis, a leading member of the Ku Klux Klan (KKK) in North Carolina, who later left the Klan and became a supporter of school integration. Ellis was a dirt-poor Southern white for whom KKK membership initially appeared to offer recognition and social status. However, snubbed by wealthier members of the Klan, and realizing that they had the financial resources to remove their children from the public schools after integration, whereas he would not, he left the KKK. Putting himself at risk of attack from his erstwhile KKK colleagues, he instead began actively to cooperate with civil rights activists. Over time he developed affective relations with some of them, and he learned how the realities of poor black lives shared some affinities with his own. He struggled to ensure that harmonious school integration took place, not only to the benefit of poor white children such as his own but also out of a deep concern for black children. In concluding the book Alcoff admits to a certain sympathy for Ellis. He was himself a victim of deeply oppressive circumstances, and he found a way to resist them by acting at once on behalf of others as well as himself within a multiracial community of activists. Whites who contest white supremacy are not 'allies' but rather 'activists in their own right', she insists (p. 204).

This is a courageous book to have written. For, given the climate of race politics in the era of 'Black Lives Matter', Alcoff's project is likely to prove contentious. It may make many antiracists, be they 'white exceptionalists' or 'race eliminativists', 
white or nonwhite, uncomfortable or even angry. Some may object that her very focus on the question of how whiteness could come to be lived more positively is posed from the site of her own (albeit marginal) white privilege; or that pursuing her question is merely a distraction from the main project, which still should be to combat white racism and to empower nonwhites. Alcoff certainly does not deny that combatting racism and empowering nonwhites remain vital struggles. However, if race identities are unlikely to disappear in the foreseeable future then she is surely correct that it matters not only to whites but also to nonwhites - and to the struggle itself against racism - that we consider what whiteness could become other than an assertion of white supremacy. Alcoff's book thus initiates an important conversation. It opens up new avenues in critical race and whiteness studies that deserve to be pursued further.

Sonia Kruks

Oberlin College, Oberlin, OH 44074, USA

sonia.kruks@oberlin.edu 